\title{
PEMANFAATAN TEPUNG CANGKANG KERANG SEBAGAI BAHAN FORTIFIKAN PADA KERIPIK JAGUNG YANG DIKONSUMSI ANAK DAN REMAJA
}

\author{
Sata Yoshida Srie Rahayu \\ Program Studi Biologi, FMIPA, Universitas Pakuan \\ Email : sata_rahayu@unpak.ac.id
}

\begin{abstract}
ABSTRAK
Tepung cangkang kerang Anodonta woodiana dapat ditambahkan dalam pembuatan produk pangan seperti keripik. Penambahan tersebut bertujuan untuk meningkatkan nilai gizi khususnya kalsium dan protein pada camilan yang dibutuhkan oleh anak berkebutuhan khusus dengan cara fortifikasi. Metode penelitian ini dilakukan dengan pembuatan produk olahan keripik dalam tiga formula, yaitu tanpa penambahan tepung kerang, dengan penambahan 3\% serta penambahan 5\%. Keripik dibuat untuk dikonsumsi oleh anak (usia7 - 9 tahun) dan remaja (usia 10 - 18 tahun). Uji yang dilakukan meliputi uji organoleptik, uji hedonik, analisis protein dan kalsium. Hasil uji organoleptik terhadap 3 formula keripik jagung yang dibuat memiliki karakteristik yang berbeda terhadap parameter rasa dan tekstur. Hasil analisis parameter warna, aroma, rasa dan kerenyahan yang dianalisis menggunakan perangkat lunak SPSS versi 36 menunjukkan bahwa formula yang paling disukai adalah formula 3 dengan penambahan tepung cangkang kijing 5\%. Kadar protein dalam sampel keripik jagung pada formula 3 diperoleh sebesar 8,49\%. Rata-rata kadar protein memenuhi syarat SNI 01-2886-2000 yakni lebih dari 5\%. Kadar kalsium dari tepung kerang Anodonta woodiana yang digunakan pada keripik jagung yang dihasilkan pada penelitian ini memiliki nilai tinggi yaitu sebesar 29,8\%sedangkan kadar kalsium dari keripik jagung adalah 16,8\%.
\end{abstract}

Kata kunci: tepung cangkang kerang, Anodonta woodiana, keripik jagung, fortifikasi

\section{UTILIZATION OF MUSSEL SHELL FLOUR AS CALCIUM FORTIFICATION IN CORN CHIPS CONSUMED BY CHILDREN AND TEENAGER}

\begin{abstract}
Flour of Anodonta woodiana shells may be added in the manufacture of food products such as chips. The aim of addition is to increase the nutritional value, especially calcium and protein on snacks needed by children with special needs through fortification. This research method was done by making products chips in three formulas: without the addition of shells flour, the addition of $3 \%$, and 5\%. Chips were made for consumption by children (7- 9 years old) and teenager (10 - 18 years old). Tests performed included organoleptic test, hedonic test, protein and calcium analysis. The results of organoleptic test between three formulas of produced corn chips have different characteristics in flavor and texture parameters. The results of the analysis of parameters of color, aroma, flavor and crispiness analized by SPSS software version 36 showed that the most preferred formula is the third formula with the addition $5 \%$ of shell flour. The protein content of formula 3 is $8.49 \%$. The average protein content complies with SNI 01-2886-2000 which is more than 5\%. Calcium levels of Anodonta woodiana shells flour used on corn chips generated in this study had a high calcium levels of $29.8 \%$ whereas calcium levels of chips are $16,8 \%$.
\end{abstract}

Key words: shells flour, Anodonta woodiana, corn chips, fortification 


\section{PENDAHULUAN}

Konsumsi kalsium pada kelompok anak (usia 7 - 9 tahun) dan remaja (usia 10 18 tahun) masih rendah. Keripik jagung adalah salah satu snak yang paling disukai tapi kandungan kalsiumnya rendah. Pembuatan keripik jagung yang menggunakan jagung brondong merupakan sumber karbohidrat dan protein yang cukup tinggi, juga merupakan sumber vitamin dan mineral, yang bermanfaat bagi kesehatan, antara lain kalsium (Ca), fosfor $(\mathrm{P})$, dan vitamin. Kadar $\mathrm{Ca}$ dan $\mathrm{P}$ pada keripik jagung umumnya relatif rendah yaitu $6 \%$ dan $4 \%$.

Tepung Cangkang kijing kaya akan kalsium sehingga bila difortifikasikan pada kripik jagung akan memperbaiki mutu gizi kripik. Cangkang Kijing merupakan salah satu komoditas yang memiliki potensi sebagai sumber kalsium. Kijing Taiwan (Anodonta woodiana) merupakan jenis kerang yang hidup dikolam, danau dan perairan lainnya yang banyak terdapat di perairan Darmaga, Bogor (Wardhani, 2009). Kijing merupakan sumber protein hewani yang cukup murah sehingga banyak dikonsumsi masyarakat. Cangkang kijing merupakan limbah padat yang belum dimanfaatkan secara optimal. Selama ini limbah padat yang berupa cangkang hanya dimanfaatkan sebagai salah satu materi hiasan dinding, hasil kerajinan atau sebagai campuran pakan ternak, padahat cangkang kijing dapat dimanfaatkan sebagai tepung untuk memenuhi kalsium dalam tubuh (Wardhani, 2009).

Berdasarkan penelitian Rahayu dkk (2013), limbah cangkang kijing Taiwan dapat diolah menjadi bentuk tepung. Tepung cangkang kijing Taiwan yang diperoleh memiliki kandungan proksimat meliputi kadar air, kadar abu, kadar lemak, kadar protein dan kadar kalsium. Kadar air yang dihasilkan dari cangkang kijing 0,54\%, kadar abu $55,31 \%$, kadar protein $3,01 \%$, kadar lemak $0,4 \%$ dan kalsium $29,8 \%$, fosfor $0,11 \%$ dan magnesium $0,12 \%$.

Tepung cangkang kijing Taiwan yang diperoleh mengandung kalsium yang cukup tinggi, sehingga dapat dijadikan bahan fortifikasi pada olahan pangan fungsional berupa keripik jagung, untuk meningkatkan nilai gizi khususnya kalsium yang dibutuhkan oleh anak berkebutuhan khusus. Fortifikasi adalah penambahan zat gizi mikro pada makanan yang dimakan secara teratur dan dapat menghantarkan zat gizi mikro pada populasi yang luas melalui makanan yang dikonsumsi setiap hari (Muchtadi 2006). Fortifikasi ditentukan berdasarkan kebutuhan kalsium harian, nilai RDA (Reccomended Daily Allowance) dan penerimaan konsumen. Jumlah mineral yang difortifikasi tidak boleh terlalu banyak yaitu tidak melebihi $20-25 \%$ (FAO, 2002).

Salah satu usaha fortifikasi adalah membuat produk keripik jagung dengan penambahan tepung cangkang kijing Taiwan. Menurut Santoso (2006), keripik jagung merupakan salah satu produk olahan jagung hasil pemasakan alkali yang paling populer, biasanya berupa keripik atau chips berbentuk bundar gepeng dengan ukuran ketebalan yang berbeda-beda di tiap negara. Keripik jagung merupakan produk pangan yang menggunakan bahan pangan serealia jagung.

Berdasarkan uraian diatas maka dilakukan penelitian tentang penambahan cangkang kijing Taiwan yang telah diolah menjadi tepung untuk memperkaya kalsium dari keripik jagung. Keripik jagung yang dihasilkan dapat dijadikan sebagai alternatif makanan camilan berkalsium tinggi untuk remaja dan orang dewasa. Pemanfaatan limbah cangkang kijing Taiwan ini diharapkan dapat meningkatkan nilai ekonomi serta dapat menjadi alternatif penanganan limbah cangkang kijing Taiwan yang selama ini kurang dimanfaatkan.

Tujuan penelitian ini adalah untuk menentukan karakteristik fisik dan kandungan gizi (kalsium) beberapa formula keripik jagung yang diperkaya dengan tepung cangkang kijing Taiwan.

\section{METODE PENELITIAN}

\section{Alat}

Alat yang digunakan untuk membuat keripik jagungantara lain: AAS (Atomic Absorption Spectroscopy tipe AA7000), cawan petri, alat penggilingan (pasta bike), food prosesor 
(Philips $\left.{ }^{\circledR}\right), \quad$ kjedahl, kompor $\quad\left(\right.$ Rinnai $\left.^{\circledR}\right)$, Moisture balance (AND MX SOR ${ }^{\circledR}$ ), pipet tetes, soxhlet, Spektrofotometer, tanur $\left(\mathrm{Ney}^{\circledR}\right)$, timbangan, alat gelas, dan lain- lain.

\section{Bahan}

Bahan untuk pembuatan keripik jagung terdiri dari bahan utama yaitu tepung Cangkang Kijing Taiwan, jagung kering popcorn $\left(\right.$ Giant $\left.^{\circledR}\right)$, asam sulfat $\left(\mathrm{H}_{2} \mathrm{SO}_{4}\right)$, natrium hidroksida $(\mathrm{NaOH})$, asam klorida $(\mathrm{HCl})$, heksana, asam nitrat $\left(\mathrm{HNO}_{3}\right)$, ammonium molibdat, ammonium vanadat, kalium dihydrogen fosfat, air, kapur sirih, garam, bubuk bawang putih. Bahan kimia yang digunakan bermerk Sigma yang diproduksi oleh Sigma-Aldrich Pte Ltd, Singapore.

\section{Cara Kerja}

Tepung cangkang dibuat dari cangkang kijing Taiwan yang diperoleh dari Dramaga, Bogor. Berdasarkan metode Rahayu dkk (2013). Pembuatan produk olahan keripik jagung dibuat menjadi tiga formula masingmasing menggunakan jumlah fortifikan tepung cangkang kerang yang berbeda yaitu 0; 7,5 dan 12,5 gram (Tabel 1).

Cara pembuatan keripik jagungcangkang kerang yaitu diambil jagung kering sebanyak $250 \mathrm{~g}$ dicuci dalam baskom yang berisi air sampai bersih, dimasukan kedalam larutan kapur sirih, kemudian dimasak selama 2 jam dengan api yang sedang dan terus menerus diaduk selama 1- 2 jam. Setelah selesai direndam dalam air kapur sirih selama 24 jam, kemudian dicuci kembali sampai bersih dan dihancurkan menggunakan Food Prosesor sampai halus. $250 \mathrm{~g}$ bubur jagung ditambahkan tepung cangkang kijing, garam dan bubuk bawang, kemudian dicetak menggunakan alat penggiling dengan ketebalan $1 \mathrm{~mm}$, dikeringkan dengan oven kemudian digoreng.

\section{Uji Organoleptik}

Uji ini meliputi penilaian terhadap karakteristik kripik jagung, meliputi warna, aroma, rasa dan tekstur.

\section{Uji Hedonik}

Uji ini dilakukan terhadap 20 panelis dengan cara memberikan 3 sampel kepada panelis terhadap parameter warna, aroma, rasa dan kerenyahan dan mengisi kertas kuisioner yang telah disediakan.

\section{Uji Kerenyahan}

Kerenyahan diuji berdasarkan tingkat kemudahan patah suatu bahan pangan, dalam hal ini keripik jagung-cangkang kerang. Besarnya tingkat kerenyahan ditunjukkan dengan nilai $F_{\text {break }}$ (kemudahan patah) terkecil/rendah.Makin mudah sampel keripik patah, maka nilai $F_{\text {break-nya makin kecil yang }}$ berarti tekstur keripik tersebut makin baik (renyah).

\begin{tabular}{cccc}
$\begin{array}{c}\text { Tabel 1. Formula Pembuatan Produk } \\
\text { Olahan Keripik Jagung } \\
\text { Jumlah Bahan }(\mathbf{g}) \\
\text { Bahan }\end{array}$ & \multicolumn{3}{c}{} \\
\cline { 2 - 4 } & F I & F II & F III \\
\hline Tepung cangkang kijing & 0 & 7,5 & 12,5 \\
Jagung & 250 & 250 & 250 \\
Garam & 3 & 3 & 3 \\
Bubuk bawang putih & 5 & 5 & 5 \\
Air & 10 & 10 & 10 \\
\hline
\end{tabular}

\section{Analisis Protein}

Pengujian kadar protein dilakukan dengan metode Kjedhal. Sebanyak 0,5-1,0 g sampel ditimbang kemudian dimasukkan ke dalam labu Kjeldahl $100 \mathrm{~mL}$. Campuran katalis selenium sebanyak $2 \mathrm{~g}$ dan $25 \mathrm{~mL}$ $\mathrm{H}_{2} \mathrm{SO}_{4}$ pekat ditambahkan ke dalam sampel. Campuran kemudian dipanaskan dalam pemanas listrik hingga mendidih dan larutan menjadi berwarna jernih kehijau-hijauan $( \pm 2$ jam). Tahap ini dilakukan di dalam lemari asam. Campuran yang telah mendidih dan berubah warna menjadi jernih kehijauhijauan, kemudian dibiarkan dingin dimasukkan kedalam labu ukur $100 \mathrm{~mL}$ lalu diencerkan dengan aquadest sampai tanda batas. Sebanyak $5 \mathrm{~mL}$ campuran dimasukan kedalam alat penyuling, ditambahkan $5 \mathrm{~mL}$ $\mathrm{NaOH} 30 \%$ dan beberapa tetes indikator phenolptalein. Campuran kemudian disuling selama 10-15 menit atau hingga penampung berubah warna dengan penampung distilat adalah $10 \mathrm{~mL}$ larutan asam borat $2 \%$ yang 
telah diberikan beberapa tetes indikator. Campuran distilat kemudian dititar dengan larutan $\mathrm{HCl}$ 0,01 N (DepKes RI, 1992). Kadar protein sampel dapat dihitung dengan menggunakan rumus berikut :

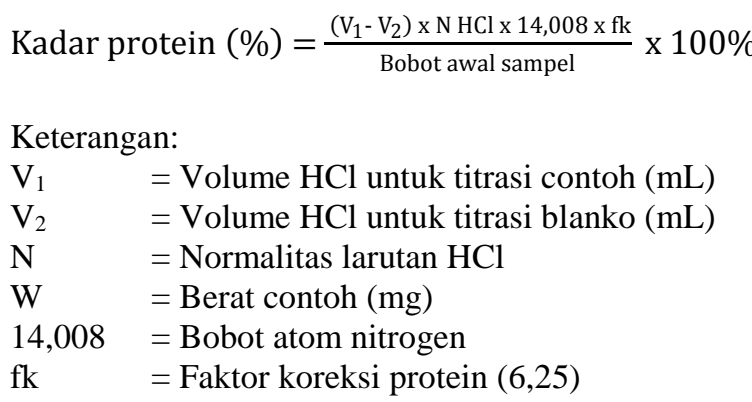

\section{Analisis Kalsium}

Preparasi Sampel kalsiumdengan cara pada sampel yang akan mengalami pengujian mineral dilakukan proses pengabuan basah terlebih dahulu. Sebanyak $1 \mathrm{~g}$ sampel dimasukkan kedalam erlenmeyer $150 \mathrm{~mL}$, ditambahkan $5 \mathrm{~mL} \mathrm{HNO}_{3}$ kedalam labu erlenmeyer dan dibiarkan selama 1 jam. Selanjutkan dipanaskan diatas hotplate selama \pm 4 jam, dan didinginkan. Ditambahkan 0,4 $\mathrm{mL} \mathrm{H}_{2} \mathrm{SO}_{4}$ pekat, kemudian dipanaskan kembali. Setelah terjadi perubahan warna dari dari coklat menjadi kuning, sampel tersebut ditambahkan campuran $\mathrm{HCIO}_{4}$ dan $\mathrm{HNO}_{3}$ sebanyak $3 \mathrm{~mL}$, dipanaskan kembali selama \pm 15 menit. Selanjutnya sampel ditambahkan $2 \mathrm{~mL}$ aquadest dan 0,6 ml HCL pekat, kemudian dipanaskan kembali sampai larut dan didinginkan. Setelah larut, sampel tersebut kemudian diencerkan menjadi $100 \mathrm{~mL}$ didalam labu takar.

\section{Pembuatan Kurva Kalibrasi Kalsium}

Pembuatan larutan baku kalsium karbonat Larutan baku disiapkan dengan melarutkan 0,624 g kalsium karbonat dalam $25 \mathrm{~mL}$ HCL $3 \mathrm{~N}$ dalam labu ukur $250 \mathrm{~mL}$ kemudian diencerkan sampai tanda dengan air suling (1000 ppm). Dari larutan ini dipipet 10 mL kedalam labu ukur 100 mL kemudian dicukupkan volumenya sampai tanda dengan air suling (100 ppm). Dari larutan ini dipipet 1, 2, 3, 4 dan $5 \mathrm{~mL}$ kemudian dimasukkan kedalam labu ukur $10 \mathrm{~mL}$ dan dicukupkan

volumenya dengan air suling hingga batas tanda sehingga diperoleh larutan baku dengan konsentrasi 10, 20, 30, 40 dan 50 ppm.

\section{Penentuan Kadar Kalsium dalam Sampel}

Pengukuran serapan kalsium dalam sampel secara Spektrofotometer Serapan Atom. Larutan sampel diukur serapannya dengan alat spektrofotometer serapan atom pada panjang gelombang 422,7 $\mathrm{nm}$ menggunakan lampu katoda kalsium.

\section{Persen AKG (Kalsium dan Protein) Keripik Jagung}

Persen Angka Kecukupan Gizi (AKG) kalsium dan protein dari sampel persajian dapat dihitung sebagai berikut:

$$
\begin{aligned}
& \text { Persen AKG (kalsium) }= \\
& \frac{\text { kalsium keripik (persajian) }}{\text { AKG kalsium }} \times 100 \%
\end{aligned}
$$

\section{HASIL DAN PEMBAHASAN \\ Hasil Uji Mutu Sediaan Keripik Jagung Uji Organoleptik}

Uji organoleptik pada suatu produk perlu dilakukan untuk menilai seberapa besar minat konsumen terhadap produk yang dihasilkan. Panelis akan memberi penilaian khusus terhadap warna, aroma, rasa dan tekstur keripik jagung dengan menggunakan skala hedonik. Pengujian ini dilakukan untuk mengetahui penilaian masing-masing terhadap produk keripik yang diujikan (Rampengan dkk., 1985). Hasil uji organoleptik terhadap 3 formula keripik jagung-tepung kerang yang dibuat memiliki karakteristik yang berbeda terhadap parameter rasa dan tekstur. Perbedaan tersebut diakibatkan karena perbedaan bahan baku yang digunakan karena adanya jumlah penambahan tepung cangkang kijing pada formula 2 dan 3 keripik jagung. Hasil pengujian organoleptik bahwa yang paling diminati oleh panelis adalah formula 3 (Tabel 2). 
Tabel 2.Hasil Uji Organoleptik Sediaan Keripik Jagung

\begin{tabular}{ccccc}
\hline \multirow{2}{*}{ Formula } & \multicolumn{4}{c}{ Pengujian Organoleptik } \\
\cline { 2 - 5 } & Warna & Aroma & Rasa berpasir & $\begin{array}{c}\text { Tekstur } \\
\text { (renyah) }\end{array}$ \\
\hline Formula 1 & $\begin{array}{c}\text { Kuning } \\
\text { Keemasan (Gb 1) } \\
\text { Formula 2 }\end{array}$ & Khas & - & ++ \\
Kuning & Keemasan (Gb 1) & Khas & ++ & + \\
Formula 3 & $\begin{array}{c}\text { Kuning Keemasa } \\
\text { (Gb 1) }\end{array}$ & Khas & + & + \\
\hline
\end{tabular}

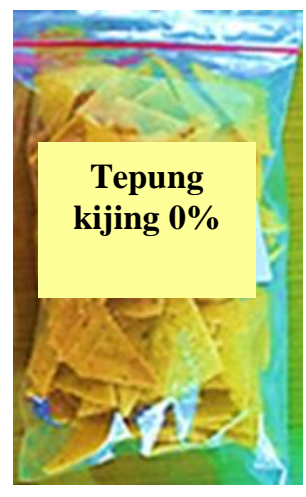

Formula 1

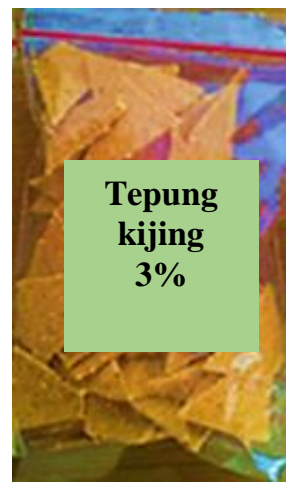

Formula 2

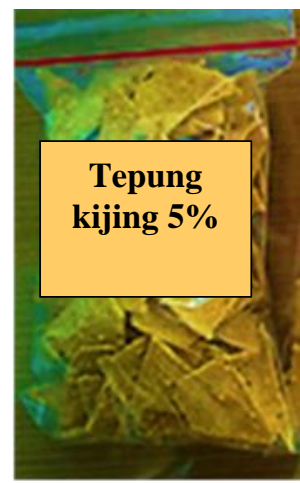

Formula 3

Gambar 1: keripik dari tiga formula

\section{Uji Hedonik}

Pengujian hedonik bertujuan untuk mencari produk keripik jagung hasil fortifikasi tepung cangkang Kijing Taiwan yang disukai oleh masyarakat. Dari hasil kuesioner diketahui bahwa formula yang paling disukai adalah penambahan tepung cangkang kijing 5\% (formula 3).

Berdasarkan analisis statistik (ANOVA) diperoleh hasil bahwa tidak ada pengaruh perbedaan sampel terhadap warna, aroma, rasa dan tekstur. Hal ini disebabkan karena bahan baku yang digunakan sama.

\section{Kadar Protein}

Analisis kadar protein dilakukan dengan menggunakan metode Kjeldahl. Prinsip dari metode Kjeldahl ini adalah pengukuran kadar protein secara tidak langsung dengan mengukur kadar nitrogen dalam sampel dengan cara destruksi, destilasi dan titrasi. Kadar protein yang dianalisis hanya pada formula yang paling diminati oleh panelis yaitu formula 3 .
Hasil kadar protein dalam sampel keripik jagung pada formula 3 diperoleh sebesar $8,49 \%$. Rata-rata kadar protein yang memenuhi syarat SNI 2000 yakni harus lebih dari 5\%. Pada formula 3 kadar protein yang diperoleh sesuai dengan kadar air yang di tetapkan oleh SNI 01-2886-2000. Menurut Winarno (2004) protein merupakan zat makanan yang penting bagi tubuh manusia, karena berfungsi sebagai bahan bakar dalam tubuh dan juga sebagai bahan pembangunan dan pengatur.

\section{Kadar Kalsium}

Anak-anak dan usia dewasa sangat membutuhkan asupan kalsium dalam jumlah yang cukup, hal ini dikarenakan kalsium berfungsi dalam pembentukan dan pertumbuhan tulang dan gigi yang kuat. Hasil analisis kadar kalsium pada sediaan keripik jagung formula 3 diperoleh sebesar 16,8\%. Hasil tersebut menunjukkan bahwa penambahan tepung cangkang Kijing Taiwan pada sediaan keripik jagung dari formula 3 menghasilkan kadar kalsium yang sangat 
tinggi. Kadar kalsium dari tepung cangkang Kijing Taiwan yang digunakan pada penelitian ini adalah 29,8\% (Rahayu dkk., 2013). Sehingga keripik jagung yang dianalisis kandungan kalsiumnya adalah yang paling diminati oleh panelis, yaitu formula 3 dapat dikatakan memiliki kadar kalsium tinggi.

Menurut Sianturi (2002), suatu makanan dapat dikatakan mengandung kasium yang tinggi jika dapat memenuhi 20 persen AKG kalsium. Dengan demikian keripik jagung yang dihasilkan dari formula 3 dapat diklaim sebagai makanan berkalsium tinggi. Setiap sachet dengan berat $50 \mathrm{~g}$ mengandung kalsium $840 \mathrm{mg}$. Kebutuhan kalsium pada anak - anak usia 7 - 9 tahun sebanyak $700 \mathrm{mg}$ per hari (FAO, 2002) memerlukan sediaan keripik jagung sebanyak $(840: 700) \times 100 \%=120 \%$ (AKG 1 sachet). Pada usia remaja usia 10 - 18 tahun kebutuhan kalsium $1300 \mathrm{mg}$ per hari memerlukan sediaan keripik jagung sebanyak (840:1300) x $100 \%=64,6 \%$ (AKG 1,5 sachet). Pada usia dewasa dengan kebutuhan kalsium 1000 mg per hari dibutuhkan sebanyak 1,5 sachet sediaan keripik jagung.

Berdasarkan penelitian kali ini, diperoleh angka kecukupan gizi (AKG) keripik jagung yang bahan baku jagung dengan penambahan tepung cangkang Kijing Taiwan yang kaya akan kalsium. Penambahan tepung cangkang Kijing Taiwan dianjurkan sebagai saran penyajian dengan tujuan untuk dapat memenuhi kalsium sesuai dengan angka kecukupan gizi khususnya bagi anak - anak dan remaja yang sedang dalam proses pertumbuhan.

\section{SIMPULAN DAN SARAN Simpulan}

Hasil uji organoleptik terhadap 3 formula keripik jagung yang dibuat memiliki karakteristik yang berbeda terhadap parameter rasa dan tekstur dan yang paling diminati adalah formula 3 .

Hasil analisis parameter warna, aroma, rasa dan kerenyahan menunjukkan bahwa formula yang paling disukai adalah formula 3 dengan penambahan tepung cangkang kijing
5\%. Kadar protein dalam sampel keripik jagung pada formula 3 diperoleh sebesar $8,49 \%$. Rata-rata kadar protein memenuhi syarat SNI 01-2886-2000 yakni lebih dari 5\%. Kadar kalsium dari tepung kerang Anodonta woodiana yang digunakan pada keripik jagung yang dihasilkan pada penelitian ini memiliki nilai tinggi yaitu sebesar 29,8\% sedangkan kadar kalsium dari keripik jagung adalah $16,8 \%$.

\section{Saran}

Setelah melakukan penelitian ini disarankan agar: (1). Dilakukan uji hedonik untuk mengetahui tingkat kesukaan atau ketidaksukaan konsumen tersebut terhadap keripik jagung. (2). Dilakukan analisis kandungan proksimat untuk mengetahui kontribusi Energi terhadap AKG (3). Dilakukan analisis mineral besi dan fosfor untuk mengetahui kandungan kedua mineral tersebut pada keripik.

\section{DAFTAR PUSTAKA}

AOAC. 1995. Official Methods of Analisis. Association of Official Analitycal Chemist. Washington D.C. USA.

Departemen Kesehatan Republik Indonesia. 1995. Farmakope Indonesia, Edisi IV. Jakarta.

FAO. 2002. Protein sources for the animal feed industry. Expert Consultation and Workshop, Bangkok.

Muchtadi, D. 2006. Konsep Keamanan Fortifikasi Pangan. Food Review Vol 1: 48-50.

Rahayu, S.Y.S., T. Aminingsih dan M. Miranti. 2013. Potensi Kalsium Kijing Taiwan (Anodonta woodiana) untuk Fortifikasi Tortilla Chips Kaya Protein dan Kalsium. Bogor: Fakultas Matematika Dan Ilmu Pengetahuan Alam Universitas Pakuan Bogor.

Rampengan, V., J. Pontoh dan D.T. Semebel. 1985. Dasar- Dasar Pengawasan Mutu Pangan. Badan Kerja Sama Perguruan Tinggi Negeri Indonesia Bagian Timur, Ujung Padang. 
Santoso, B, W. Mushollaeni, dan N. Hidayat. 2006. Tortilla. Trubus Agrisarana, Surabaya.

Sianturi, G. 2002. Perlu Lebih Banyak Zat Gizi. Indonesian Network Nutrition. Jakarta.

SNI 01-2886-2000. Makanan Ringan Ekstrudat. Jakarta: Badan Standarisasi Nasional.

Wardhani, Y.K. 2009.Karakteristik Fisik Dan Kimia Tepung Cangkang Kijing Lokal (Pilsbryoconcha exilis). Bogor: Fakultas Perikanan Dan Ilmu Kelautan Institut Perikanan Bogor.

Winarno, F.G. 2004.Pengantar Teknologi Pangan. Gramedia. Jakarta 
Fitofarmaka, Vol.5, No.2, Desember2015 ISSN:2087-9164 